\title{
PERTANIAN BERORIENTASI KEWIRAUSAHAAN: FAKTOR PEMICU GENERASI MUDA MEMULAI BISNIS PERTANIAN
}

\section{ENTREPRENEURSHIP-ORIENTED AGRICULTURE: TRIGGERING FACTORS FOR YOUNG GENERATION TO START AGRICULTURE BUSINESS}

\author{
Gema Wibawa Mukti*, Dini Rochdiani, Iwan Setiawan \\ Program Studi Agribisnis, Fakultas Pertanian Universitas Padjadjaran \\ *E-mail: gema.wibawa@unpad.ac.id
}

(Diterima 12-11-2021; Disetujui 22-01-2022)

\begin{abstract}
ABSTRAK
Kewirausahaan menjadi isu yang penting di Indonesia karena dianggap dapat mengatasi berbagai permasalahan pembangunan, seperti penciptaan lapangan kerja baru dan mendukung terwujudnya pertumbuhan ekonomi. Tujuan dari penelitian dalam makalah ini adalah untuk mengetahui faktorfaktor yang mendorong petani untuk memulai kegiatan usaha baru, baik itu usahatani maupun usaha non pertanian yang dapat menjadi sumber pemasukan bagi mereka. Pada penelitian ini digunakan beberapa pendekatan/ perspektif untuk mengeksplorasi faktor-faktor yang memicu petani muda untuk memulai kegiatan bisnis baru, yaitu 1) perspektif sosiologi pedesaan dalam kewirausahaan pertanian, 2) perspektif peluang dalam kewirausahaan pertanian dan 3) perspektif sumberdaya dalam kewirausahaan pertanian. Petani wirausaha yang selalu mencari ide bisnis baru, melihat dan menangkap peluang-peluang baru dan mampu memanfaatkan sumberdaya yang mereka miliki sangat diperlukan untuk pengembangan pertanian di wilayah perdesaan. Petani yang memiliki karakteristik kewirausahaan merupakan aktor yang dapat diharapkan untuk mengembangkan perekonomian masyarakat perdesaan. Intinya semua tipe petani yang telah dijelaskan dalam penelitian ini dapat memberikan kontribusi terhadap pembangunan sektor pertanian, menciptakan lapangan kerja baru, kegiatan ekonomi baru, penemuan sumberdaya unik dan mempertahankan eksistensi pertanian di Indonesia sebagai negara agraris.
\end{abstract}

Kata Kunci : Kewirausahaan, Pertanian, petani muda, bisnis baru

\begin{abstract}
Entrepreneurship is an important issue in Indonesia because it is considered to be able to overcome various development problems, such as creating new jobs and supporting the realization of economic growth. The purpose of this study is to determine the factors that encourage farmers to start new business activities, both farming and non-agricultural businesses that can be a source of income for them. The study uses several approaches/perspectives to explore the factors that trigger young farmers to start new business activities, namely 1) rural sociology perspective in agricultural entrepreneurship, 2) opportunity perspective in agricultural entrepreneurship and 3) resource perspective in agricultural entrepreneurship. Entrepreneurial farmers who are always looking for new business ideas, see and capture new opportunities and are able to utilize the resources they have are indispensable for agricultural development in rural areas. Farmers who have entrepreneurial characteristics are actors who can be expected to develop the economy of rural communities. In essence, all types of farmers described in this study can contribute to the development of the agricultural sector, create new jobs, new economic activities, discover unique resources and maintain the existence of agriculture in Indonesia as an agricultural country.
\end{abstract}

Keywords: Entrepreneurship, Agriculture, Young Farmer, New Business 


\section{PENDAHULUAN}

Pembangunan kewirausahaan di Indonesia dipandang sebagai sebuah fundamental penting untuk mewujudkan pembangunan ekonomi Indonesia yang kuat (Frinces, 2010). Pemerintah dalam sepuluh tahun terakhir berupaya untuk menciptakan lebih banyak wirausahawirausaha baru, salah satunya melalui Kementerian Pertanian (2020) untuk mencetak petani muda yang berorientasi kewirausahaan. Kewirausahaan menjadi isu yang penting di Indonesia karena dianggap dapat mengatasi berbagai permasalahan pembangunan, seperti penciptaan lapangan kerja baru dan mendukung terwujudnya pertumbuhan ekonomi.

Kewirausahaan telah menjadi bagian penting dalam kebijakan pertanian Indonesia yang berfungsi sebagai bagian penting dalam upaya sektor pertanian dalam menghadapi berbagai perubahan yang ada saat ini, salah satunya pandemi Covid 19. Badan Penyuluhan dan Pengembangan Sumberdaya Manusia Pertanian Kementerian Pertanian (2020) menekankan bahwa saat ini Indonesia membutuhkan petani muda yang berorientasi kewirausahaan, yaitu mereka yang memiliki loyalitas dan integritas untuk memajukan pertanian Indonesia secara modern dan berorientasi ekspor agar Indonesia menjadi negara agraris yang mandiri pangan.

Penataan sumberdaya manusia pertanian sebagai petani yang memiliki karakter kewirausahaan menuntut peningkatan kegiatan wirausaha di kalangan petani. Penguatan keterampilan kewirausahaan dan fasilitasi pemasaran telah menjadi isu penting (Mikko Vesala et al., 2007) sebagai solusi yang mungkin dapat ditawarkan dalam pengembangan pertanian di Indonesia umumnya, dan di Jawa Barat khususnya. Pertanian memiliki sumberdaya yang sangat potensial untuk dimanfaatkan dalam aktivitas kewirausahaan, seperti misalnya sebagai bahan baku makanan atau pariwisata (Alsos et al., 2003). Petani dalam hal ini menjadi pelaku utama dalam kegiatan kewirausahaan, bagian dari komunitas pertanian dan dan menjadi sumberdaya potensial dalam aktivitas kewirausahaan (Cheshire \& Woods, 2013). Petani muda di Jawa Barat telah memiliki pengalaman dalam usahatani, memperoleh pengetahuan dari generasi ke generasi, dan mereka dikenal secara historis sebagai petani yang mandiri dan mampu beradaptasi dengan berbagai perubahan yang ada. 
Rumah tangga petani selalu berupaya untuk mencari pendapatan lain di luar usatani sebagai upaya untuk memenuhi kebutuhan hidup mereka sehari-hari. Perilaku petani dan rumah tangga petani dalam menghadapi berbagai perubahan yang ada, baik itu perubahan lingkungan maupun perubahan pasar, telah menjadi bidang kajian yang penting dalam bidang pertanian (Lans et al., 2017). Penelitian-penelitian yang telah ada sebelumnya masih kurang membahas mengenai faktor-faktor yang memicu petani untuk memulai kegiatan wirausaha (Alsos et al., 2003). Untuk mendorong kegiatan kewirausahaan di kalangan petani, diperlukan pengetahuan mengenai faktor apa yang memicu petani untuk berwirausaha pertanian. Tujuan dari penelitian dalam makalah ini adalah untuk mengetahui faktor-faktor yang mendorong petani untuk memulai kegiatan usaha baru, baik itu usahatani maupun usaha non pertanian yang dapat menjadi sumber pemasukan bagi mereka.

\section{Kerangka Teoritis}

Pada penelitian ini digunakan beberapa pendekatan untuk mengeksplorasi faktor-faktor yang memicu petani muda untuk memulai kegiatan bisnis baru. Pendekatan pertama adalah dari sudut pandang sosiologi pedesaan, yang melihat strategi rumah tangga petani untuk bertahan hidup (Meert, 2000). Kemajemukan dinilai sebagai strategi adaptasi dalam aktivitas ekonomi, sebagai respon yang diberikan terhadap perubahan-perubahan yang terjadi pada lingkungan sekitar. Perubahan harga di pasar dan adanya penyesuaian kebijakan pertanian telah mendorong petani untuk mencari peluang-peluang bisnis lainnya, yang dapat menopang kehidupan mereka atau usaha utama mereka saat ini (usahatani) menjadi lebih "survive" (Babb \& Babb, 1992). Menjalankan aktivitas bisnis tambahan diluar usahatani sebagai pekerjaan utama petani sering dipahami sebagai respon mereka terhadap rendahnya harga pasar komoditas, atau upaya mereka untuk mencari tambahan bagi kehidupan mereka (Eikeland \& Lie, 1999; Evans \& Llbery, 1993; Kageyama, 2019).

Pertanian pada beberapa penelitian yang telah dilakukan, masih jarang menjadi latar empiris dalam sebuah penelitian kewirausahaan. Penelitian mengenai kewirausahaan banyak dilakukan pada sektor non pertanian, sehingga dalam penelitian ini peneliti mencoba untuk melihat kewirausahaan 
dalam sektor pertanian di wilayah perdesaan. Memulai bisnis baru dalam penelitian ini dipandang sebagai sebuah upaya untuk mengeksploitasi peluang bisnis yang ada (Shane \& Venkataraman, 2000). Dalam perspektif Berorientasi sumberdaya, kewirausahaan dilihat sebagai upaya untuk melakukan akuisisi terhadap sumberdaya. Sumberdaya yang unik dianggap dapat mengembangkan kewirausahaan pada suatu wilayah (Zahra, 2021). Kombinasi dari beberapa sudut pandang ini dianggap dapat memberikan pengetahuan yang lebih dalam untuk mengetahui faktor-faktor yang memicu petani untuk memulai sebuah usaha baru di luar kegiatan utamanya sebagai petani.

\section{Perspektif Sosiologi Pedesaan Dalam}

\section{Kewirausahaan Pertanian}

$\begin{array}{lll}\text { Sosiologi } & \text { pedesaan } & \text { telah } \\ \text { memberikan } & \text { penekanan } & \text { pada }\end{array}$

restrukturisasi agraria, yaitu bagaimana masyarakat dapat mendapatkan akses yang lebih baik terdapat lahan sebagai sumberdaya ekonomi yang vital di wilayah perdesaan. Sosiologi pedesaan telah memberikan pelajaran tentang bagaimana dan mengapa pertanian skala kecil dapat bertahan di tengah semakin berkembangnya industrialisasi dan transformasi ekonomi kapitalis (Monke, 2019). Rumah tangga petani sebagai unit analisis sosial dan ekonomi dalam penelitian ini lebih menekankan pada rumah tangga yang mengalokasikan sumberdaya bagi aktivitas ekonomi mereka, baik untuk pertanian maupun non pertanian (Iles, 2017).

Aktivitas ekonomi majemuk (Pluractivity) sebagai respon terhadap berbagai kesulitan yang melanda usahatani pada masa pandemi covid 19 dan juga perubahan pertanian secara global. Hal ini merupakan upaya petani skala kecil untuk bertahan hidup pada masa krisis seperti yang terjadi saat ini. Pluraktivitas didefinisikan sebagai penciptaan pendapatan lebih dari satu kegiatan ekonomi (Bojnec, 2017; Klikocka et al., 2021). Pemahaman mengenai pendapatan lain di luar pertanian dalam penelitian ini adalah pendapatan yang diperoleh dari bidang usaha lain yang dijalankan oleh petani (usaha baru), bukan pendapatan yang berasal dari upah sebagai buruh/pekerja lepas. Pada saat membahas faktor-faktor yang berhubungan dengan pluraktivitas, tentunya kedua hal ini harus dibedakan. Rumah tangga pertanian mungkin akan mengadopsi pola yang berbeda tergantung pada kondisi pertanian, 
peluang kerja yang terdapat dalam bidang pertanian dan rumah tangga itu sendiri bergantung pada kenyataan yang terjadi dalam kehidupan mereka (Fuller, 1990).

Berdasarkan perspektif sosiologi pedesaan, alasan utama seorang petani mencari peluang bisnis baru adalah sebagai kebutuhan untuk mempertahankan atau meningkatkan pendapatan usahatani yang mereka lakukan saat ini (Sugiharto, 2020). Beberapa penelitian juga mempertimbangkan adanya motif sosial budaya yang dapat mendorong petani untuk mencari peluang bisnis baru (Igwe et al., 2020; Jarquín et al., 2017). Studistudi yang dilakukan memperlihatkan bahwa motivasi petani untuk mencari peluang bisnis baru (pluractivity) bukan hanya sebagai strategi adaptasi petani dalam aktivitas ekonomi, namun hal tersebut juga merupakan sebuah upaya dari rumah tangga petani agar dapat mempertahankan usahatani dan tetap tinggal di wilayah perdesaan. Upaya tersebut menjadi motivasi bagi petani untuk mempertahankan petani sebagai usaha keluarga yang telah mereka kerjakan secara turun temurun (Adesugba et al., 2020). Aktivitas ekonomi yang "plural" ini menjadi sebuah aktivitas yang akan terus dipertahankan, karena masyarakat telah terbiasa dengan adaptasi ekonomi yang didasarkan pada kombinasi dari berbagai aktivitas ekonomi. Oleh karena itu, memulai bisnis baru bagi petani dapat termotivasi karena keinginan untuk mempertahankan bertani sebagai gaya hidup, bebas dan mandiri untuk berwirausaha, atau juga keinginan untuk menjaga tradisi perdesaan yang cenderung menggabungkan berbagai kegiatan.

\section{Perspektif Peluang Dalam}

\section{Kewirausahaan Pertanian}

(Shane \& Venkataraman, 2000) mendefinisikan bahwa kewirausahaan adalah upaya untuk menemukan dan mengeksploitasi peluang bisnis yang menguntungkan. Kondisi yang tidak sempurna atau tidak menguntungkan yang terjadi dalam lingkungan bisnis telah mendorong seorang pengusaha untuk memanfaatkan sumberdaya secara efisien untuk "membidik" peluang yang dianggap dapat memberikan manfaat bagi mereka (He et al., 2020). Kewirausahaan dalam perspektif peluang dilihat sebagai eksploitasi peluang yang dirasakan melalui pengorganisasian sumberdaya dan kolaborasi yang dilakukan oleh para pelaku usaha yang terlibat (Landström \& Johannisson, 2001). 
Perspektif peluang kewirausahaan menekankan peluang bisnis sebagai pendorong utama terjadinya kegiatan kewirausahaan dan menjadi pemicu bagi seorang pengusaha (petani) untuk memulai suatu bisnis baru (Shane \& Venkataraman, 2000). Pada prosesnya, beberapa individu mungkin mampu untuk mengeksplotasi peluang-peluang bisnis yang ada, lebih cepat mengidentifikasi peluang tersebut dibandingkan dengan yang lain. Kemampuan untuk menangkap dan mengeksploitasi sebuah peluang tentu perlu didukung oleh informasi yang cukup dan kemampuan kognitif untuk mengevaluasi informasi tersebut. Peluang bisnis merupakan sebuah perpaduan dari kondisi lingkungan yang memadai dan juga kemampuan dari seorang wirausaha untuk mengakses dan memproses informasi yang dia dapatkan dari lingkungan nya (Ucbasaran et al., 2008).

Individu pengusaha menjadi aktor utama yang memiliki peran penting dalam memulai suatu bisnis baru berdasarkan peluang yang berhasil dia identifikasi dalam prosesnya (Puhakka, 2012). Individu pengusaha ini didefinisikan sebagai seseorang yang memiliki portofolio pengusaha (Ucbasaran et al., 2008). Petani pada prinsipnya adalah sebuah usaha yang serupa dengan usaha kecil lainnya yang bergerak di wilayah perdesaan, dan petani merupakan pemilik atau manajer usahatani yang dijalankan nya (Carter, 2003). Petani sebagai seorang pebisnis yang memulai sebuah usaha baru, dapat menemukan dan memanfaatkan berbagai peluang yang ada dengan tetap mempertahankan usahatani sebagai mata pencaharian utama mereka. Sebelumnya telah dikemukakan bahwa seorang pengusaha memiliki kemampuan untuk menemukan peluang-peluang bisnis baru (Shane \& Venkataraman, 2000). Bagi petani, pengetahuan mereka sebelumnya dalam mendirikan dan menjalankan bisnis pertanian telah memberikan akses informasi dan pengetahuan yang dapat menjadi dasar dari ide-ide bisnis pertanian berharga lainnya (Zahra, 2011). Pengalaman usaha membuat petani dapat mengevaluasi informasi dengan baik dan mengambil kesimpulan berupa peluang bisnis yang dapat memberikan manfaat bagi mereka.

Bisnis pertanian yang telah dijalani sebelumnya dapat menjadi sumber ideide baru, yang terkait dengan pengetahuan awal yang dimiliki petani terkait dengan bisnis mereka saat ini. Pengetahuan bisnis yang telah dimiliki, kapabilitas petani dan juga jaringan sosial 
yang telah dimiliki meningkatkan sensitivitas seseorang terhadap usaha yang sedang dijalankan nya (Hayton et al., 2011). Berdasarkan hal tersebut maka dapat dikatakan bahwa pertanian yang Berorientasi kewirausahaan merupakan hasil dari kemampuan petani dalam menemukan dan memanfaatkan peluang bisnis yang terkait dengan pengetahuan awal mereka.

\section{Perspektif Sumberdaya Dalam}

\section{Kewirausahaan Pertanian}

Perspektif sumberdaya

dikembangkan oleh para ahli manajemen untuk memahami perusahaan dari sudut pandang ketersediaan sumberdaya yang heterogen (Rotefoss, 2001). Kemampuan mengorganisasi sumberdaya yang beragam dapat menciptakan kemampuan unik bagi perusahaan dalam mengembangkan keunggulan kompetitif dan berkelanjutan. Sumberdaya terdiri dari aset materiil dan immateriil yang berada dalam kendali perusahaan untuk dipergunakan bagi kepentingan bisnis mereka. Sumberdaya yang diperlukan dalam sebuah aktivitas bisnis diantaranya adalah manusia, fisik (lahan), keuangan, teknologi, kepercayaan (trust) dan modal sosial (Barney, 1991; Dubos, 2017;
Khan, et al., 2019; Lin, 2017; Linder et al., 2020).

Pengelolaan sumberdaya merupakan aspek penting bagi seorang wirausaha dalam memulai suatu bisnis baru, bahkan beberapa ahli mengatakah bahwa hal ini menjadi aspek terpenting untuk memulai bisnis baru (Alvarez \& Busenitz, 2001). Kemampuan seorang wirausaha untuk mengorganisasi sumberdaya menjadi modal penting yang dapat menentukan apakah dia dapat memulai bisnis baru. Seorang wirausaha yang telah bergerak dalam bisnis pertanian pada jangka waktu tertentu akan memiliki akses terhadap sumberdaya, seperti misalnya sarana produksi, tenaga kerja dan pasar produk pertanian. Mereka juga dapat mengelola sumberdaya seperti jaringan bisnis, logistik pertanian dan lain-lain untuk memulai bisnis baru (Alsos et al., 2003). Berdasarkan perspektif sumberdaya, keunggulan kompetitif dibangun berdasarkan(satu atau kombinasi) sumberdaya yang dimiliki, dimana sumberdaya tersebut berharga dan unik, tidak mudah untuk ditiru oleh para pesaing. Petani yang memiliki akses terhadap sumberdaya tersebut tentu akan lebih mudah untuk memicu lahir/munculnya bisnis baru. Akses 
terhadap jejaring pasar, sarana produksi pertanian, lahan dan tenaga kerja pertanian merupakan aset berharga bagi petani, sehingga dapat mendorong mereka untuk melakukan diversifikasi usaha pertanian.

\section{METODE PENELITIAN}

Objek penelitian dalam makalah ini adalah petani dan rumah tangga petani. Rumah tangga menjadi objek penelitian karena merupakan unit dasar produksi dan pengambilan keputusan dalam kegiatan usahatani. Rumah tangga petani merupakan elemen kunci dalam penelitian untuk memahami berbagai perubahan yang terjadi dalam sektor pertanian (Alsos et al., 2003; Herrero et al., 2014). Fakta bahwa keputusan yang terkait dengan pengembangan usahatani paling sering ditentukan dalam rumah tangga petani (Louhichi \& y Paloma, 2014), menjadikannya sebagai unit analisis yang dianggap paling relevan dalam penelitian ini. Rumah tangga dianggap sebagai unit analisis yang tepat untuk mempelajari proses seorang petani memulai suatu usaha baru.

Data primer diperoleh dari hasil wawancara dan observasi mendalam yang dilakukan pada 20 orang petani (informan) di dua sentra agribisnis Jawa
Barat, yaitu Kecamatan Pangalengan dan Kecamatan Pasirjambu, Kabupaten Bandung. Karakteristik petani pada kedua kecamatan tersebut secara umum hampir sama dengan petani pada wilayah lainnya di Jawa Barat. Pertaniandi wilayah Jawa Barat secara umum adalah pertanian skala kecil, mempekerjakan anggota keluarga sebagai tenaga kerja dalam kegiatan usahatani. Informan dalam penelitian ini diambil secara purposive, yaitu petani yang telah memulai kegiatan usaha baru di luar bidang pertanian, atau mereka yang memiliki rencana yang sungguh-sungguh untuk memulai usaha baru di luar bidang pertanian. Selanjutnya informan dalam penelitian ini adalah petani yang yang telah berumah tangga, dimana proses pengambilan keputusan dilakukan bersama pasangan mereka (rumah tangga petani).

Kegiatan usaha baru ini didefinisikan sebagai usaha lain di luar usahatani yang dapat menambah pendapatan petani. Usaha baru ini dapat berupa usahatani lainnya yang dapat menambah usaha utama menjadi lebih berkembang, atau usaha lain di luar usahatani yang dapat menambah pendapatan rumah tangga petani. Petani yang menjadi informanadalah petani yang memiliki usahatani dalam bidang 
hortikultura, dan telah menjalankan usahanya tersebut selama minimal 5 tahun.

\section{HASIL DAN PEMBAHASAN}

Petani informan (20 orang) dalam penelitian ini akan dilihat dari motivasi utama mereka untuk memulai sebuah usaha baru. Analisis dalam penelitian ini berusaha untuk mengungkapkan 3(tiga) jenis wirausaha Berorientasi pertanian, yaitu wirausaha yang Berorientasi sumberdaya, wirausaha Berorientasi peluang dan wirausaha Berorientasi sosiologis. Penelitian ini mencoba untuk melihat bagaimana petani dan rumah tangga petani menggunakan jejaring usahanya, menetapkan tujuan bisnis dan ide bisnis mereka, menetapkan sumberdaya yang mereka miliki dan bagaimana mereka dapat melihat peluang yang muncul di sekitar mereka. Petani informan memiliki karakteristik yang berbeda-beda, dilihat dari skala usaha, kebutuhan modal, orientasi usaha dalam rumah tangga petani dan lain sebagai nya.

Usahatani dapat melibatkan petani sebagai kepala keluarga atau beberapa anggota keluarga. Rumah tangga petani memegang peranan penting sebagai produsen utama hasil pertanian yang dikonsumsi oleh masyarakat dunia
(Davidova \& Thomson, 2014). Pendapatan rumah tangga petani dapat berasal dari kegiatan usahatani atau usaha lainnya yang dapat menghasilkan pemasukan bagi mereka.

\section{Petani Wirausaha dari Sudut Pandang Sosiologi}

Petani wirausaha dalam sudut pandang sosiologi terdiri dari petani yang memiliki usaha yang beragam, dimana mereka selalu berusaha keras untuk mendapatkan sumber-sumber pendapatan baru yang dapat menambah pendapatan mereka di luar pendapatan usahatani. Usaha baru petani umumnya dilakukan untuk mendukung usahatani yang mereka kerjakan, sehingga dapat setidaknya bertahan, dan apabila memungkinkan dapat meningkatkan usahatani sebagai mata pencaharian utama petani. Komitmen petani untuk mempertahankan usahatani adalah pilihan hidup yang harus mereka lakukan, karena latar belakang mereka yang berasal dari pertanian.

Sebagian besar informan dapat dikategorikan sebagai petani majemuk/plural, artinya petani informan memiliki usaha lain yang dapat menopang usaha utama yang mereka jalankan saat ini. Informan melihat usahatani sebagai mata pencaharian 
utama, sehingga mereka memiliki kewajiban untuk menjaga keberlangsungannya. Mereka memilih untuk membuka usaha baru karena cashflow dari usahatani utama adalah musiman(3-5 bulan), sedangkan kebutuhan hidup mereka bulanan. Kondisi ini mendorong mereka untuk mencoba menjalankan usaha baru yang dapat memenuhi kebutuhan nya tersebut. Petani informan lebih memilih usaha baru dibandingkan apabila mereka bekerja pada orang lain, karena dianggap sulit untuk membagi waktu dengan pekerjaan utama mereka sebagai petani. Alasan lainnya adalah petani informan merasa kesulitan untuk menyesuaikan diri dengan pekerjaan baru, karena merasa bahwa hal tersebut tidak sesuai dengan latar belakang mereka, sehingga merasa tidak memiliki keahlian untuk bekerja di sektor non pertanian.

Usaha baru yang dikerjakan oleh petani dengan karakter majemuk biasanya memiliki skala yang kecil, masih melekat pada kegiatan usahatani utama mereka. Kepemilikan dan teaga kerja sepenuhnya berasal dari rumah tangga petani, dan masih merupakan bagian dari aktivitas usahatani utama. Usaha baru yang mereka lakukan menyesuaikan dengan beban kerja pertanian yang bervariasi, sehingga dapat memberikan kontribusi bagi mereka. Beberapa jenis usaha baru yang biasanya dikerjakan oleh petani seperti misalnya pemanfaatan asset yang terdapat di lahannya saat ini, misalnya menyewakan traktor/saprodi lainnya, menyewakan sebagian lahannya kepada petani lain atau mereka menjadi penampung hasil panen dari lingkungan sekitarnya, sehingga mereka mendapatkan pendapatan tambahan sebagai seorang pedagang (pedagang pengumpul/bandar).

Faktor pendorong petani untuk melakukan ini umumnya berasal dari orang-orang di sekitarnya yang telah melakukan hal serupa sebelumnya. Hal ini menginspirasi mereka untuk melakukan hal yang sama, sehingga dapat menambah pendapatan bagi mereka. Proses memulai usaha baru merupakan proses ujicoba, dimana mereka mencoba beberapa jenis usaha, yang kemudian mereka memilih usaha mana yang paling menguntungkan bagi mereka. Beberapa diantaranya mungkin menghasilkan kerugian, namun proses tersebut menjadi pembelajaran bagi mereka dan tetap berusaha untuk menemukan bisnis baru yang menguntungkan. 
Aktivitas bisnis baru telah memberikan tambahan finansial yang cukup bagi petani untuk dapat mempertahankan atau mengembangkan usahatani yang mereka jalankan. Petani informan yang juga menjadi pedagang pengumpul mampu memenuhi kuota permintaan pasar, sehingga kepercayaan pasar dapat terjaga. Kondisi ini tentu merupakan sebuah jaminan pasar yang dapat menjaga usatani utama mereka tetap berjalan, dan pemasukan bagi rumah tangga petani juga dapat terjaga dengan baik.

Seringkali petani diminta untuk fokus pada produksi, fokus untuk menghasilkan produk yang berkualitas sesuai dengan kebutuhan pasar, namun di sisi lain mereka juga membutuhkan cashflow yang berkelanjutan untuk pemenuhan kebutuhan sehari-hari dari rumah tangga petani. Kondisi ini mendorong mereka untuk mengembangkan usaha lainnya, mengembangkan kreativitas mereka dalam usahataninya. Petani seperti ini memberikan kontribusi dalam kewirausahaan pertanian, yaitu petani yang berusaha secara kreatif untuk meningkatkan pendapatan dan kesejahteraan mereka sendiri (Bessant, 2006).
Petani Wirausaha Berorientasi

\section{Sumberdaya}

Pengusaha yang mencoba untuk mengeksploitasi sumberdaya unik yang mereka miliki didorong oleh keinginan untuk memanfaatkan sumberdaya tersebut secara optimal, sehingga dapat memberikan benefit bagi diri dan lingkungan nya. Sumberdaya unik ini dapat berupa materil maupun immaterial, seperti misalnya benih unggul, pengetahuan/pengalaman budidaya komoditas unik dan pengalaman unik seperti magang jepang misalnya. Sumberdaya unik ini biasanya terhubung ke usahatani dan/atau rumah tangga petani sebagai pemilik dari sumberdaya ini. Sumberdaya ini juga dapat terkoneksi pada kelompok tani/komunitas lokal yang dapat digunakan setiap individu yang terdapat dalam kelompok/komunitas tersebut.

Pengusaha yang memiliki minat untuk mengeksploitasi sumberdaya umumnya merupakan tinggal di wilayah pertanian, namun mereka tidak memiliki ikatan yang kuat terhadap kegiatan pertanian itu sendiri. Ikatan mereka terhadap pertanian tidak seperti petani plural yang berwirausaha dalam bidang pertanian. Pertanian/usahatani umumnya memiliki kontribusi terbesar terhadap 
pendapatan rumah tangga petani. Bagi petani yang berorientasi pada eksploitasi sumberdaya mungkin menganggap bahwa usaha baru menjadi sesuatu yang lebih penting bagi mereka dibandingkan dengan pertanian sebagai mata pencaharian utama mereka. Mereka mungkin lebih memilih usaha baru sebagai penopang kehidupan mereka karena memberikan pendapatan yang lebih besar, kualitas kehidupan yang lebih baik.

Rumah tangga petani dalam kasus ini memilih kegiatan bisnis baru untuk memanfaatkan sumberdaya unik yang mereka miliki. Mereka memiliki peluang lain seperti bekerja di pabrik ataumemperbesar skala usahataninya, namun hal ini membuat mereka tidak dapat memanfaatkan sumberdaya unik yang mereka miliki. Usaha baru yang dikerjakan oleh rumah tangga petani memiliki skala yang lebih besar dari apa yang dikerjakan oleh petani plural, namun kesamaannya adalah mereka sama-sama masih menggunakan rumah tangga petani sebagai aktor utama dalam aktivitas usaha baru yang mereka jalankan. Umumnya anggota rumah tangga petani memiliki kegiatan usaha yang lebih beragam, yang mungkin usaha tersebut tidak terkait dengan aktivitas usahatani. Apabila kita melihat dari sisi manajemen keuangan, aktivitas usaha ini memiliki pencatatan keuangan yang benar-benar terpisah dari aktivitas usahatani. Petani informan yang memiliki usaha baru Berorientasi sumberdaya misalnya petani yang memiliki usaha warung dan dikelola oleh istrinya sebagai bagian dari rumah tangga petani. Petani informan lain menjadikan anaknya menjadi pedagang sayuran khas jepang karena memiliki jaringan pasar yang luas (sumberdaya unik). Dalam kegiatan usaha ini membutuhkan modal yang bervariasi, tergantung dari jenis sumberdaya yang ingin mereka gunakan oleh rumah tangga petani tersebut.

Pemanfaatan sumberdaya dalam bentuk materil biasanya membutuhkan modal yang lebih besar daripada pemanfaatan sumberdaya dalam bentuk immateril. Beberapa petani informan saat ini justru tidak lagi bertani, karena mereka memilih untuk menjadi pendamping usaha atau trainer pertanian untuk lembaga pemerintah/non pemerintah. Hal ini mereka lakukan karena mereka memiliki pengetahuan dan pengalaman dalam bidang tersebut, yang kemudian menjual kemampuan tersebut sebagai pendapatan baru bagi mereka. Petani informan yang beralih menjadi 
pedagang perantara memilih bisnis baru nya tersebut atas dasar akses pasar yang mereka miliki. Informan yang memiliki akses pasar tentu akan memanfaatkan hal tersebut sebagai bisnis baru mereka, sehingga dapat memberikan pendapatan yang mungkin lebih baik daripada pendapatan mereka sebelumnya.

Kasus lain dari petani informan yang berupaya untuk memadukan sumberdaya lahan dan pengetahuan menjadi kombinasi sumberdaya yang unik. Petani informan mencoba untuk membuka usahatani produk/komoditas sayuran Jepang, sebagai hasil belajar yang bersangkutan di Jepang sebagai petani magang. Produk yang dihasilkan tentunya unik dan tidak memiliki pesaing, dengan pasar yang khusus pula, sehingga sulit untuk ditiru oleh petani lain. Pada kasus ini, sumberdaya dan kemampuan unik yang terkait dengan kegiatan pertanian (usahatani) menjadi keunggulan kompetitif pada saat mereka memulai bisnis baru.

Beberapa dari petani informan juga mulai memanfaatkan kemampuan mereka dalam pemasaran digital produk pertanian. Mereka mulai mengakses media sosial untuk menjual produk mereka, atau berkolaborasi dengan startup-startup yang bergerak dalam pemasaran produk pertanian, seperti misalnya tanihub/sayurbox. Pengetahuan dan jejaring mereka menjadi sumberdaya unik yang mendorong mereka membuat bisnis baru atau juga model bisnis baru bagi bisnis pertanian mereka saat ini, sehingga dapat meningkatkan penjualan dan pada ujungnya meningkatkan pendapatan mereka.

Aktivitas usaha baru dengan mengeksploitasi sumberdaya unik dapat memberikan kontribusi positif terhadap peningkatan pendapatan rumah tangga. Mereka dapat memanfaatkan sumberdaya yang unik, meskipun seringkali sumberdaya tersebut adalah sumberdaya lokal. Pada prinsipnya pemanfaatan sumberdaya yang dapat meningkatkan usaha adalah salah satu bentuk kontribusi terhadap kegiatan ekonomi secara umum.

\section{Petani Wirausaha Berorientasi Peluang}

Petani wirausaha pada tipe ini memulai bisnis baru karena mereka memiliki ide baru dan ingin mengeksploitasi ide tersebut. Ide bisnis ini tidak selalu berasal dari sumberdaya pertanian, namun dapat berasal dari manapun yang memiliki potensi untuk dikembangkan. Seringkali untuk mengeksploitasi ide bisnis, petani 
PERTANIAN BERORIENTASI KEWIRAUSAHAAN:

FAKTOR PEMICU GENERASI MUDA MEMULAI BISNIS PERTANIAN

Gema Wibawa Mukti, Dini Rochdiani, Iwan Setiawan

wirausaha dengan tipe seperti ini bersedia

untuk mencari sumberdaya yang

dibutuhkan dengan pengorbanan tertentu

yang mereka bersedia keluarkan. Petani seperti ini bersedia untuk berinvestasi lebih banyak dibandingkan dengan tipe petani wirausaha lainnya (tipe 1 dan 2) (Tabel 1).

Tabel 1. Orientasi Petani Wirausaha

\begin{tabular}{|c|c|c|c|}
\hline & $\begin{array}{c}\text { Petani Wirausaha } \\
\text { (Berorientasi Sosiologi) } \\
\text { (Tipe 1) }\end{array}$ & $\begin{array}{c}\text { Petani Wirausaha } \\
\text { (Berorientasi } \\
\text { Sumberdaya) } \\
\text { (Tipe 2) } \\
\end{array}$ & $\begin{array}{c}\text { Petani Wirausaha } \\
\text { (Berorientasi peluang) } \\
\text { (Tipe 3) }\end{array}$ \\
\hline $\begin{array}{l}\text { Petani informan } \\
\text { (orang) }\end{array}$ & 11 & 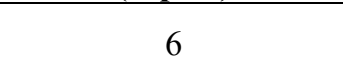 & 3 \\
\hline $\begin{array}{l}\text { Dasar Motivasi } \\
\text { berwirausaha }\end{array}$ & $\begin{array}{l}\text { Usahatani yang } \\
\text { berkelanjutan }\end{array}$ & $\begin{array}{l}\text { Memanfaatkan sebaik- } \\
\text { baik nya sumberdaya } \\
\text { unik yang mereka } \\
\text { miliki }\end{array}$ & Eksploitasi Ide Bisnis \\
\hline Tujuan utama & $\begin{array}{l}\text { Keberlanjutan usahatani } \\
\text { yang sedang dijalankannya } \\
\text { saat ini dan sebagai upaya } \\
\text { untuk menambah } \\
\text { pendapatan rumah tangga } \\
\text { petani }\end{array}$ & $\begin{array}{l}\text { Aktivitas bisnis baru } \\
\text { dilakukan untuk } \\
\text { memanfaatkan } \\
\text { sumberdaya yang } \\
\text { dimiliki petani saat ini. } \\
\text { Mereka berpikir } \\
\text { bahwa sumberdaya } \\
\text { yang ada harus } \\
\text { dimanfaatkan secara } \\
\text { produktif. }\end{array}$ & $\begin{array}{l}\text { Petani memulai bisnis } \\
\text { baru untuk } \\
\text { mengeksploitasi ide } \\
\text { bisnis yang muncul dari } \\
\text { peluang - peluang yang } \\
\text { terdapat di lingkungan } \\
\text { sekitar mereka. }\end{array}$ \\
\hline Sumber Ide & $\begin{array}{l}\text { Sesama petani dan } \\
\text { kelompok tani di } \\
\text { lingkungan sekitar mereka }\end{array}$ & $\begin{array}{l}\text { Sumberdaya unik yang } \\
\text { dimiliki oleh petani }\end{array}$ & $\begin{array}{l}\text { Berdasarkan peluang } \\
\text { yang mereka dapatkan } \\
\text { (bervariasi) }\end{array}$ \\
\hline $\begin{array}{l}\text { Hubungan Dengan } \\
\text { Pertanian }\end{array}$ & $\begin{array}{l}\text { Mereka memiliki pilihan } \\
\text { untuk hidup sebagai petani } \\
\text { yang sejahtera, dimana } \\
\text { mereka melihat pertanian } \\
\text { sebagai hidup mereka dan } \\
\text { "wajib" menjaga usahatani } \\
\text { yang mereka jalankan } \\
\text { sebagai mata pencaharian } \\
\text { utama. }\end{array}$ & $\begin{array}{l}\text { Pertanian adalah usaha } \\
\text { utama bagi rumah } \\
\text { tangga petani, namun } \\
\text { aktivitas bisnis baru } \\
\text { mungkin menjadi } \\
\text { penting bagi mereka } \\
\text { untuk menambah } \\
\text { pendapatan dan juga } \\
\text { kualitas kehidupan } \\
\text { mereka }\end{array}$ & $\begin{array}{l}\text { Usahatani adalah sebuah } \\
\text { bisnis yang prospektif, } \\
\text { seperti halnya aktivitas } \\
\text { bisnis baru yang mereka } \\
\text { kerjakan, dimana } \\
\text { aktivitas nya tersebut } \\
\text { bervariasi untuk setiap } \\
\text { informan. }\end{array}$ \\
\hline \multirow{5}{*}{$\begin{array}{l}\text { Karakteristik } \\
\text { Aktivitas Bisnis Baru } \\
\text { Petani }\end{array}$} & Skala usaha kecil & Sumberdaya unik & Skala usaha bervariasi \\
\hline & $\begin{array}{l}\text { Membutuhkan dana yang } \\
\text { rendah }\end{array}$ & $\begin{array}{l}\text { skala usaha kecil, } \\
\text { namun lebih besar dari } \\
\text { usaha petani wirausaha } \\
\text { tipe } 1\end{array}$ & $\begin{array}{l}\text { Skala usaha lebih besar } \\
\text { dibandingkan dengan } \\
\text { yang lain }\end{array}$ \\
\hline & $\begin{array}{l}\text { Terkait dengan aktivitas } \\
\text { usahatani yang mereka } \\
\text { kerjakan }\end{array}$ & $\begin{array}{l}\text { Membutuhkan besaran } \\
\text { modal yang bervariasi }\end{array}$ & $\begin{array}{l}\text { Membutuhkan modal } \\
\text { yang lebih besar }\end{array}$ \\
\hline & $\begin{array}{l}\text { Kepemilikan dan tenaga } \\
\text { kerja hanya dari rumah } \\
\text { tangga petani }\end{array}$ & $\begin{array}{l}\text { biasanya tidak terlalu } \\
\text { terkait dengan } \\
\text { aktivitas usahatani }\end{array}$ & $\begin{array}{l}\text { Seringkali merupakan } \\
\text { bisnis yang terpisah dari } \\
\text { bisnis utama (usahatani) }\end{array}$ \\
\hline & & & $\begin{array}{l}\text { Kepemilikan dan tenaga } \\
\text { kerja mungkin ada yang } \\
\text { berasal dari luar rumah } \\
\text { tangga petani }\end{array}$ \\
\hline
\end{tabular}


Investasi tentunya disertai dengan risiko yang menyertainya, artinya petani yang bersedia untuk melakukan investasi untuk usaha baru nya tentu memiliki karakteristik sebagai seorang wirausaha, yaitu berani mengambil risiko dalam memulai usaha baru. Risiko yang kemungkinan muncul tidak hanya dalam bentuk finansial, namun juga risiko waktu yang mungkin akan tersita untuk memenuhi ide bisnis yang ada dalam pikiran mereka, sehingga usahatani sebagai mata pencaharian utama mungkin akan sedikit terbengkalai.

Aktivitas usaha baru berdasarkan ide bisnis/peluang yang muncul umumnya melibatkan lebih dari satu orang yang terlibat secara aktif di awal. Pelibatan aktor lain dalam memulai usaha baru dapat melibatkan anggota keluarga (rumah tangga petani) atau orang lain yang berasal dari luar rumah tangga petani. Petani tipe terakhir ini umumnya tidak terikat dengan bisnis pertanian secara mendalam. Mereka terlibat dengan aktivitas pertanian karena sebelumnya melihat potensi besar dalam bisnis ini, namun pada saat mereka memiliki ide bisnis lain yang mungkin memiliki potensi yang lebih baik maka mereka akan mencoba ide baru tersebut. Mereka tidak memiliki kewajiban untuk mempertahankan bisnis mereka sebelumnya. Ide bisnis ini dapat berupa ide bisnis yang benar-benar berbeda dengan bisnis pertanian yang sebelumnya mereka usahakan, atau juga ide yang dapat membuat bisnis pertanian menjadi lebih baik dengan model bisnis yang baru/berbeda dari yang sebelumnya.

Petani wirausaha pada tipe ini memiliki ikatan yang lebih lemah dengan kegiatan usahatani yang mereka kerjakan sebelumnya, dan terkadang dengan wilayah pertanian yang menjadi tempat tinggal mereka sekarang. Petani tipe ini memandang pertanian sebagai bisnis yang sama dengan bisnis lainnya di luar pertanian. Berbeda dengan petani plural yang melihat pertanian sebagai bisnis dan juga bagian dari warisan atau budaya keluarga yang harus mereka pertahankan keberadaannya. Hal ini membuat mereka tidak dapat begitu saja keluar dari usahatani dan cenderung mempertahankan usahatani nya dapat tetap eksis.

Petani berorientasi kewirausahaan memiliki cara pandang berbeda terhadap bisnis, dimana mereka akan memilih bisnis yang memiliki potensi untuk tumbuh lebih besar, apakah itu bisnis pertanian maupun bisnis non pertanian. Bisnis yang memiliki kemampuan untuk 
tumbuh lebih besar (pendapatan) akan menjadi sumber pendapatan bagi rumah tangga petani. Beberapa studi menjelaskan bahwa petani yang berorientasi kewirausahaan lebih fokus pada keuntungan bisnis dibandingkan dengan petani dua tipe yang lainnya (Díaz-Pichardo et al., 2012; McElwee, 2006). Hasil observasi terhadap 3 (tiga) orang petani yang berorientasi kewirausahaan memperlihatkan bahwa mereka akan mengalihkan sumberdaya dari pertanian kepada bisnis baru di luar pertanian, selama mereka menilai bahwa hal tersebut akan memberikan keuntungan/benefit yang lebih baik.

Bisnis baru yang dijalankan oleh rumah tangga petani pada 3(tiga) informan ini dikelola terpisah dari usahatani yang mereka usahakan sebelumnya. Petani informan memiliki harapan besar agar usaha baru nya tersebut dapat memberikan kontribusi yang lebih baik terhadap pendapatan rumah tangga nya saat ini. Usaha baru ketiga informan ini masih dalam bidang pertanian, namun dengan jenis produk/ komoditas yang berbeda dengan sebelumnya. Usahatani yang mereka usahakan sebelumnya adalah sayuran daun, sedangkan saat ini mereka mengusahakan jeruk lemon, yang pada masa pandemi Covid 19 permintaan nya mengalami kenaikan yang signifikan. Petani dengan orientasi kewirausahaan melihat pasar sebagai dasar utama mereka dalam memulai usaha. Mereka tidak lagi menjadi "follower" dari petani di sekitarnya, namun mulai mengamati perubahan pasar dan berusaha untuk memenuhi kebutuhan pasar/peluang yang tersedia.

Petani tipe ini memiliki visi yang jelas dalam bisnis nya, artinya mereka berniat untuk lebih mengembangkan bisnis mereka berdasarkan peluang dan juga ide baru yang mereka miliki. Petani informan pada penelitian ini telah memberikan kontribusi positif dalam perekonomian, yaitu dengan membuka lapangan pekerjaan baru, atau menjadi inspirasi bagi generasi muda di wilayahnya untuk menjadi seorang berwirausaha dalam bidang pertanian. Usahatani baru mereka menjadi penting bagi lingkungan tempat tinggal mereka, berkontribusi positif terhadap perekonomian desa. Mereka juga memberikan jenis kegiatan kewirausahaan yang unik dan dapat menjadi inspirasi bagi generasi muda di Kabupaten Bandung khususnya, dan Indonesia umumnya. 


\section{KESIMPULAN}

Penelitian ini membahas petani wirausaha berdasarkan 3 (tiga) perspektif, yaitu dari perspektif sosiologi, sumberdaya dan peluang bisnis. Hasil penelitian menunjukkan bahwa petani wirausaha dilihat dari ketiga perspektif tersebut memiliki beberapa perbedaan, terutama dilihat dari motivasi dan tujuan mereka memulai suatu bisnis baru, sumber ide bisnis, hubungan mereka dengan usahatani yang mereka jalankan saat ini dan karakteristik bisnis baru. Ketiga tipe petani wirausaha tersebut dipicu oleh berbagai faktor, sehingga hal ini akan berimplikasi pada penyusunan kebijakan dan penelitian di masa depan, terutama yang terkait dengan kewirausahaan pertanian.

Penelitian terhadap petani wirausaha berdasarkan perspektif sosiologis (petani plural) memperlihatkan bahwa kewirausahaan bagi mereka merupakan strategi rumah tangga petani untuk beradaptasi terhadap perubahan ekonomi yang ada saat ini. Mereka berusaha untuk mengembangkan usaha pertanian untuk memenuhi kebutuhan hidup yang semakin bertambah. Penelitian terhadap petani wirausaha berdasarkan perspektif sumberdaya dan peluang bisnis memperlihatkan suatu inisiatif yang berbeda dan seringkali diperlukan untuk meningkatkan kegiatan kewirausahaan di kalangan petani.

Petani wirausaha yang selalu mencari ide bisnis baru, melihat dan menangkap peluang-peluang baru dan mampu memanfaatkan sumberdaya yang mereka miliki sangat diperlukan untuk pengembangan pertanian di wilayah perdesaan. Mengembangkan petani dengan karakteristik tersebut tentunya memerlukan kebijakan yang dapat mendukung hal tersebut dan juga pendidikan pertanian yang lebih menitikberatkan pada kewirausahaan. Petani yang memiliki karakteristik kewirausahaan merupakan aktor yang dapat diharapkan untuk mengembangkan perekonomian masyarakat perdesaan. Intinya semua tipe petani yang telah dijelaskan dalam penelitian ini dapat memberikan kontribusi terhadap pembangunan sektor pertanian, menciptakan lapangan kerja baru, kegiatan ekonomi baru, penemuan sumberdaya unik dan mempertahankan eksistensi pertanian di Indonesia sebagai negara agraris.

\section{DAFTAR PUSTAKA}

Adesugba, M., Oughton, E., \& Shortall, S. (2020). Farm household livelihood strategies. In Routledge 
Handbook of Gender and Agriculture (pp. 315-325). Routledge.

Alsos, G. A., Ljunggren, E., \& Pettersen, L. T. (2003). Farm-based entrepreneurs: what triggers the start-up of new business activities? Journal of Small Business and Enterprise Development.

Alvarez, S. A., \& Busenitz, L. W. (2001). The entrepreneurship of resourcebased theory. Journal of Management, 27(6), 755-775.

Babb, E. M., \& Babb, S. V. (1992). Psychological traits of rural entrepreneurs. The Journal of Socio-Economics, 21(4), 353-362.

Barney, J. (1991). Firm resources and sustained competitive advantage. Journal of Management, 17(1), 99120.

Bessant, K. C. (2006). A farm household conception of pluriactivity in Canadian agriculture: Motivation, diversification and livelihood. Canadian Review of Sociology/Revue Canadienne de Sociologie, 43(1), 51-72.

Bojnec, Š . (2017). Pluriactivity, part-time farming, farm diversification, integrated and inclusive rural household development in contemporary economics. Integrated Peasant Economy in a Comparative Perspective Alps, Scandinavia and Beyond, 415-436.

Carter, S. (2003). Entrepreneurship in the farm sector: indigenous growth for rural areas. In Entrepreneurship in Regional Food Production. Entrepreneurship in Regional Food Production, 22-47.

Cheshire, L., \& Woods, M. (2013). Globally engaged farmers as transnational actors: Navigating the landscape of agri-food globalization. Geoforum, 44, 232242.
Davidova, S., \& Thomson, K. (2014). Family farming in Europe: challenges and prospects. Indepth Analysis. Directorate General for Internal Policies, Policy Department B: Structural and Cohesion Policies. European Parliament's Committee on Agriculture and Rural Development, Brussels.

Díaz-Pichardo, R., Cantú-González, C., López-Hernández, P., \& McElwee, G. (2012). From Farmers to Entrepreneurs: The Importance of Collaborative Behaviour. The Journal of Entrepreneurship, 21(1), 91-116. https://doi.org/10.1177/097135571 102100104

Dubos, R. (2017). Social capital: Theory and research. Routledge.

Eikeland, S., \& Lie, I. (1999). Pluriactivity in rural Norway. Journal of Rural Studies, 15(4), 405-415.

Evans, N. J., \& Llbery, B. W. (1993). The pluriactivity, part-time farming, and farm diversification debate. Environment and Planning A, 25(7), 945-959.

Frinces, Z. H. (2010). Pentingnya profesi wirausaha di Indonesia. Jurnal Ekonomi Dan Pendidikan, 7(1).

Fuller, A. M. (1990). From part-time farming to pluriactivity: a decade of change in rural Europe. Journal of Rural Studies, 6(4), 361-373.

Hayton, J., Chandler, G. N., \& DeTienne, D. R. (2011). Entrepreneurial opportunity identification and new firm development processes: a comparison of family and nonfamily new ventures. International Journal of Entrepreneurship and Innovation Management, 13(1), 12-31.

He, J., Nazari, M., Zhang, Y., \& Cai, N. (2020). Opportunity-based 
entrepreneurship and environmental quality of sustainable development: A resource and institutional perspective. Journal of Cleaner Production, 256, 120390.

Herrero, M., Thornton, P. K., Bernués, A., Baltenweck, I., Vervoort, J., van de Steeg, J., ... Rufino, M. C. (2014). Exploring future changes in smallholder farming systems by linking socio-economic scenarios with regional and household models. Global Environmental Change, 24, 165-182.

Igwe, P. A., Rahman, M., Odunukan, K., Ochinanwata, N., Egbo, P. O., \& Ochinanwata, C. (2020). Drivers of diversification and pluriactivity among smallholder farmersevidence from Nigeria. Green Finance, 2(3), 263-283.

Iles, K. (2017). Transitioning Towards Small-Scale Farming: Insights from Indiana.

Jarquín Sánchez, N. H., Castellanos Suárez, J. A., \& SangermanJarquín, D. M. (2017). Pluriactivity and family agriculture: Challenges of rural development in México. Revista Mexicana de Ciencias Agrícolas, 8(4), 949-963.

Kageyama, A. (2019). PLURIACTIVITY AND AGRICULTURE IN THE STATE OF SAO PAULO. Revista de Economia e Sociologia Rural, 37(1), 145-164.

Khan, N. U., Li, S., Safdar, M. N., \& Khan, Z. U. (2019). The role of entrepreneurial strategy, network ties, human and financial capital in new venture performance. Journal of Risk and Financial Management, 12(1), 41.

Klikocka, H., Zakrzewska, A., \& Chojnacki, P. (2021). Characteristics of Models of Farms in the European Union. Sustainability, 13(9), 4772.
Landström, H., \& Johannisson, B. (2001). Theoretical foundations of Swedish entrepreneurship and small-business research. Scandinavian Journal of Management, 17(2), 225-248.

Lans, T., Seuneke, P., \& Klerkx, L. (2017).

Agricultural

Entrepreneurship. In Encyclopedia of Creativity, Invention, Innovation and Entrepreneurship (pp. 1-7). Retrieved from http://link.springer.com/10.1007/97 8-1-4614-6616-1_496-2

Lin, N. (2017). Building a network theory of social capital. Social Capital, 328.

Linder, C., Lechner, C., \& Pelzel, F. (2020). Many roads lead to Rome: How human, social, and financial capital are related to new venture survival. Entrepreneurship Theory and Practice, 44(5), 909-932.

Louhichi, K., \& y Paloma, S. G. (2014). A farm household model for agrifood policy analysis in developing countries: Application to smallholder farmers in Sierra Leone. Food Policy, 45, 1-13.

McElwee, G. (2006). Farmers as entrepreneurs: developing competitive skills. Journal of Developmental Entrepreneurship, 11(03), 187-206.

Meert, H. (2000). Rural community life and the importance of reciprocal survival strategies. Sociologia Ruralis, 40(3), 319-338.

Mikko Vesala, K., Peura, J., \& McElwee, G. (2007). The split entrepreneurial identity of the farmer. Journal of Small Business and Enterprise Development, 14(1), 48-63. https://doi.org/10.1108/146260007 10727881

Monke, E. A. (2019). Structural Change and Small Farm Agriculture in Northwest Portugal. Cornell 
University Press.

Puhakka, V. (2012). Entrepreneurial creativity as discovery and exploitation of business opportunities. EntrepreneurshipCreativity and Innovative Business Models, Rijeka, InTech, 3-24.

Rotefoss, B. (2001). A resource-based approach to the business start-up process: a longitudinal investigation.

Shane, S., \& Venkataraman, S. (2000). The promise of entrepreneurship as a field of research. Academy of Management Review, 25(1), 217226.
Sugiharto, A. (2020). Non Farm Activity, Household Expenditure, and Poverty Reduction in Rural Indonesia.

Ucbasaran, D., Alsos, G. A., Westhead, P., \& Wright, M. (2008). Habitual entrepreneurs. Now Publishers Inc.

Zahra, S. A. (2011). Entrepreneurial capability: Opportunity pursuit and game changing. 3rd Annual Conference of the Academy of Entrepreneurship and Innovation, June, 15-17.

Zahra, S. A. (2021). The Resource-Based View, Resourcefulness, and Resource Management in Startup Firms: A Proposed Research Agenda. Journal of Management, 01492063211018505. 